\title{
FAMILIES LOST AND FOUND: ORPHANS AND ORPHANHOOD IN POST-SOVIET CINEMA
}

\author{
KIRSTEN RUTSALA \\ Virginia Polytechnic Institute and State University \\ krutsala@vt.edu \\ ORCID: 0000-0002-3810-8979
}

\section{ABSTRACT}

The motif of absent fathers occurs in many Russian films, especially those produced during the Thaw, reflecting the reality of families destroyed and fragmented by World War II and the Terror. The nuclear family functions as a microcosm of the state, and in its turn the state is represented as a family; the absent father frequently stands for Stalin, the "Father of Nations," whose death has left the orphaned country in turmoil. In Russian cinema of the 1990s and 2000s, the motifs of fragmented families and orphaned children occur frequently, often representing the loss of security and defining cultural narratives in the post-Soviet landscape. This article examines the subject of both functional and actual orphanhood in Andrei Zviagintsev's film The Return and Andrei Kravchuk's film The Italian as it parallels the post-Soviet experience of uncertainty, rejection of previously held societal beliefs, and longing to return to the "small family," rather than the Soviet collective "great family" (to borrow Katerina Clark's terms from her seminal work The Soviet Novel).

KEYWORDS: Zviagintsev, Kravchuk, cinema, family, orphan.

The motif of absent fathers occurs in many Russian films, especially those produced during the Thaw, reflecting the reality of families destroyed and fragmented by World War II and the Terror. The nuclear family functions as a microcosm of the state, and in its turn the state is represented as a family; the absent father frequently stands for Stalin, the "Father of Nations," whose death has left the orphaned country in turmoil.

In Russian cinema of the 1990s and 2000s, the motifs of fragmented families and orphaned children occur frequently, often representing the loss of security and defining cultural narratives in the post-Soviet landscape. This article examines the subject of both functional and actual orphanhood in The Return and The Italian as it parallels the post-Soviet experience of uncertainty, rejection of previously held societal beliefs, and longing to return to the "small family," rather than the Soviet collective "great family" (to borrow Katerina Clark's terms from her seminal work The Soviet Novel).

When The Return opens, the two boys have lived virtually their entire lives in an apparently harmonious family arrangement with their mother and grandmother. When the father makes his unexpected appearance, Ivan, the younger boy, repeatedly questions where he came from and later wonders whether his father might be a criminal, even potentially a murderer. Although 
his brother Andrei ridicules these notions, Ivan cannot by placated by easy solutions to the mystery of his father. Ivan's questions also reflect the soulsearching of the post-Soviet years in Russian culture at large, when comforting narratives of the past had been rejected but new mythologies had yet to be developed. Nostalgia for the past, for the clear lines of delineation between "us" and "them," for the sense of patriotic pride and assurance of the position of one's country in the world, was at its peak in the early years of the new millennium. It is not coincidental that the length of the father's absence is twelve years: The Return was released in 2003, twelve years after the fall of the Soviet Union. The father in the film orphaned his boys at precisely the time the Soviet state also abandoned its children. The return of the father may be read as a national longing for former certainties, the chance to once again be a child in a paternalistic state that provided all the answers and enforced clear codes of behavior. His presence and influence on his children may indicate both the appeal and the danger of clinging to those absolutes.

It has been said that Stalinist cinema centers on the Word while Thaw cinema focuses on the image (Prokhorov 2002: 215). In the post-Soviet world of The Return, neither words nor images are ascendant; they seem at times in direct conflict with each other. The boys need visual confirmation that the man before them really is their father, which they find in the old family photograph. Nevertheless, words carry power in this film. The word Papa is weighted with emotional significance, and the father insists on being addressed this way. Andrei eagerly, even ecstatically complies, interjecting the word into nearly every sentence he addresses to his father. Ivan grudgingly mouths the word when commanded to but clearly bristles at addressing a stranger with a term that implies a close, warm relationship. When they are alone together, the boys refer to their father simply as "he" or "him." The boys have lived their entire conscious lives as functional orphans; although the father seems to assume that simply addressing him as Papa will automatically, even magically, transform these three strangers into a family, he expects too much of language.

Throughout the film, the father's use of language defines his character, his role as father, and his relationship to his sons. Ironically, he is an inarticulate man, whose interaction with the boys consists mainly of orders and occasional threats. He seems conscious at all times that his role is to teach his sons how to behave, more specifically to train them in incipient manhood. Language forms a crucial part of these lessons. For instance, in the scene at the café, the father commands Andrei to settle up the bill. Andrei has no experience of the accepted conventions of customer/waitress interaction. He calls out to the waitress, "Девушка," which he then hastily amends to "тетенька," a child's word that betrays his youth and inexperience. His father then provides the exact phrase he should use (Можно вас на минуточку?). Once again, the father supplies the language that the situation requires, and the boy parrots him, like a much younger child. Having missed out on the mundane communications of the boys' childhood, he seems 
overly invested in each moment now, intent on providing a model of both language and behavior.

In a typical Stalinist tale of the transition from childhood to adulthood, a father or father figure guides his son along this path, with Stalin once removed as the ultimate symbolic father figure. In these stories, the sons follow the predictable pattern of socialist realism, progressing from a state of "spontaneity" (стихийность) to one of "consciousness" (сознательность), with the assistance of their exclusively male mentors. As Clark points out, orphans feature frequently in these narratives: "This is because the child without a father is to that extent a child without an identity. And in the great tale of Soviet society, whether told within fiction or without, all are orphans until they find their identity in the "great family'" (Clark 2000: 135). The Return replays the Stalinist tale but subverts it. According to the socialist realist script, the boys should move from spontaneity to consciousness, rejecting their childish naivete and developing a firm commitment to their place in the collective. Instead, with the father's death they are more profoundly orphaned than before, literally alone in the wilderness. The brief experience of having a paternal mentor has certainly altered their sense of self and identity. However, it has not advanced a positive transformation in them, a deep maturity that will see them through the years to come and help them cope with crisis and hardship. Rather, their transformation can be read as ambiguous at best.

The climactic scene of the father's death is preceded by the moments of highest tension in the film. When the boys return late from fishing, the father strikes Andrei; in response Ivan threatens the father with a knife. Significantly, both boys verbally express anger and hatred for the father, though Ivan also says, "I could love you if you were different." The turmoil of emotions is clear: their desire to love their father, the years of pain due to his absence, and their disappointment and anger at his behavior and seeming lack of love for them. Their longing for a "small family" is in part an attempt to replace the Soviet "great family" that no longer exists; although the characters are too young to remember life in the USSR, they belong to a new generation, unmoored from previous comforting mythologies and adrift in the new Russia, searching for connection in personal relationships rather than societal bonds. Ivan thinks it would have been possible for them to love a less gruff, more affectionate man, the Papa they dreamed of rather than the man who demands this form of address but remains emotionally distant from them. Ivan's rejection of his father also involves assigning him a new name: "You're nobody," he says.

The first-time viewer may expect the following scenes to be transformative and cathartic, as Ivan conquers his fears and passes through a self-imposed rite of initiation by climbing the watchtower and the father follows his son, reversing the original abandonment by seeking him out with a new sense of urgency. Of course, Zviagintsev's film is far too complex and subtle to resolve itself neatly. Ivan moves through the confidence of facing his fear and toward a dangerous 
impulse for self-destruction. The father's apparently sincere desire to protect and connect with his son is obliterated as he falls to his death. The Stalinist myth of the son gradually learning from his father, emulating him and absorbing his lessons in preparation for the day the son can step into his father's shoes, has been overturned. Instead, the father (albeit unintentionally) abandons his sons, abruptly and completely. Now the boys are without a guide and must face the world with a radically altered identity. If the father is "Nobody," as Ivan furiously declared, then what does that make his sons?

Andrei takes charge of the situation, revealing a new maturity. However, it is not the maturity of socialist realist consciousness, with its clear-sighted vision of the present and optimistic view of the future. He quite explicitly takes on the father's role, repeating his words verbatim ("ручками, ручками") and aping his manner by barking orders at Ivan. Although Andrei's orphaned state has awakened a new sense of authority, it is not an unalloyed achievement. He has modeled himself on his deeply flawed father and may be in danger of losing his most appealing characteristics - his kindness, soft-heartedness, affection and compassion for his brother. Andrei has not found his own authentic voice; he has only learned to mimic his father's words. Rather than representing positive continuity between the generations, the words seem to belong to a tired script, a relic of the past.

Ivan's experience of orphanhood follows an opposite trajectory to his brother's. Instead of shouldering new responsibilities and literally taking his father's place in the driver's seat, as Andrei does, Ivan seems to undergo a regression. He becomes more childlike, no longer the adolescent rebel. Indeed, his sense of loss may be for the father of his imagination, not for the real man who died still essentially a stranger to his children. Moreover, the viewer must ask whether Andrei's hero worship is the model that Ivan should follow. Is Ivan's broken sob of yearning a better response than his earlier rejection of his father's authority? Is orphanhood preferable to being dominated and abused by an unpredictable father figure?

The film may be read in part as a cautionary tale warning against a return to earlier cultural patterns. The father figure represents not just the personal past of these two boys but the historical past of the nation, given the symbolic significance of his absence for the twelve years between 1991 and 2003. He reappears in his children's lives and sets about teaching them how to survive in both the social and the natural world. His values tend to be clear-cut, uncomplicated, and even brutal. The father's death, the ultimate orphaning of the two boys, may indicate that his principles are also empty and not worth resurrecting. He may have had some other messages, some words of wisdom or love, to communicate to his children. However, he died with these words unspoken, so they become a legacy the boys will never inherit, just as the mysterious box, the object of the quest, sinks with his corpse. The father belongs to the past; his brief presence in their lives illustrates the limitations of earlier 
values. Ivan and Andrei will now have to make their way in the world without him. Whether they will follow his example, with its simplicity and clear codes of behavior, or forge a new path of their own remains unclear.

In contrast to the fractured family of The Return, Andrei Kravchuk's 2005 film The Italian relates the story of six-year-old Vanya Solntsev, who has lived in state care since birth. The adults nominally in charge of Vanya's orphanage have abdicated virtually all responsibility for the children's care. The orphanage director, presented as well-meaning but weak, takes advantage of any opportunity to drink and escape the depressing conditions of the orphanage. In response, the children have created an alternative structure that mimics family life. One of the oldest boys, Kolyan, is the stern father figure who controls the finances and metes out justice and punishment. Natasha takes on the maternal role, nurturing the younger children, reading to them, calming their fears. At the same time, this surrogate family may also be seen as a microcosm of the Soviet system. Loyalty to the collective is prized above all. Any money acquired by the children, whether by performing odd jobs, engaging in prostitution or theft, or as gifts, must be turned over to Kolyan without question; he then decides how it will be spent (on shoes for the younger children, luxuries like ice cream or a new television, etc.).

Vanya's initial enthusiasm for his impending adoption by a kind Italian couple changes as a result of a chance encounter with the mother of one of his friends (a boy who had been adopted by a foreign couple not long before the film begins). Her arrival at the orphanage in search of her son, and her subsequent death (an apparent suicide) cause a radical shift in Vanya's perspective. It occurs to him that he has a mother, someone who is his own ("родная") and he determines to find her. The orphanage director and Kolyan, both of whom represent the older Soviet values of the "fathers" (despite the fact that Kolyan belongs to a younger generation) attempt to remind Vanya of the effect of his actions on the others: if he refuses to go to Italy, this could ruin the chances of the other children to be adopted. However, Vanya asserts his individual interests over the collective. He is a post-Soviet child, for whom the values of the "fathers" are meaningless. When the orphanage director tries to reason with Vanya, he invokes the image of Yury Gagarin, a Soviet hero and touchstone for older generations. Vanya has no idea who Gagarin was. This lack of knowledge not only reveals the cultural poverty of his existence (he knows nothing about his country's history, and no one even bothers to teach him the alphabet until he takes the initiative himself), but also represents yet another absent father figure.

Like The Return, this film rejects the Soviet socialist realist script. In that script, Vanya would have absorbed the teachings of his fathers/mentors and put aside his own selfish desires. However, Vanya asserts his individual interests over the collective. Unlike socialist realist heroes who achieve a state of political consciousness and obedience to the "fathers," Vanya rejects the values he has internalized at the orphanage and develops a new "spontaneity": an instinctive, 
elemental desire to reconnect with his mother which is entirely emotional, beyond the bounds of rational, thoughtful "consciousness."

Vanya's lack of curiosity about his actual father is significant in its completeness. At no point does he imagine anything about the man, nor does he form a plan to find him. The father stands for the defining cultural narratives of the Soviet era which have no meaning for Vanya. Nevertheless, the surrogate father figures in The Italian are among the film's most positive characters. Despite his weakness, the orphanage director seems genuinely to care for Vanya and the others. Even Kolyan's occasional brutality is combined with concern and a sense of responsibility for his "family." The night watchman at Vanya's first orphanage also possesses clear links to past Soviet values, both to the glorious victory in World War II and to Soviet literary culture in his reference to Valentin Kataev's short novel Son of the Regiment (Syn polka), whose boy hero shares the name Vanya Solntsev. This wise old man treats Vanya with nurturing kindness. He protects him from the evil adoption broker, feeds him, provides him with the information he needs to find his mother, and even offers him a permanent home. Clearly, then, despite Vanya's lack of interest in his biological father, the father figures around him offer him crucial positive links to his nation's past. While the Soviet past includes shameful and painful elements, and the rejection of the father may be approved as a way to escape those aspects of the past, the film implies that for Vanya, and by extension for the country as a whole, the generation of the "fathers" has something to teach, a sense of pride and continuity to impart.

Vanya's search for his mother carries loaded symbolic significance. The connection between mother and motherland is deeply ingrained in the Russian consciousness. Vanya's quest for his mother may be seen as a symbolic journey, representing the national need to rebuild emotional and cultural connections to Russia herself, ties that had been broken by the Soviet system. The hardships and obstacles Vanya encounters along the way indicate that this process will not be easy, but his ultimate success resonates with hope.

At the same time, the concept of motherhood is presented with considerable ambiguity in this film. With the exception of the nurturing older girl, Natasha, the potential mother figures appear in a harsh light. The worst is Madame, the corrupt adoption broker who treats the children as a commodity, her only concern the money she can earn by arranging foreign adoptions. Her conviction that money can solve all problems, her reflexive attempts at bribery, her mercenary transactional approach to human relationships reveal her character as something of a warning sign, indicating the pitfalls of a post-Soviet capitalist Russia. Alyosha Mukhin's mother, whose search for her son ends in failure when she discovers he has already been adopted, while not presented quite as ruthlessly, is nonetheless treated with considerable outrage. The orphanage director feels fully justified in shouting insults at her, manhandling her, and physically throwing her out of the building. Even kind-hearted Natasha has no sympathy for the woman ("Ask her where she's been all these years," she 
dismisses her scornfully). Although the filmmaker offers some sympathetic glimpses of Mukhina (her regret, her genuine pain at the loss of her child), the film's overall attitude reflects both Natasha's view and that of the night watchman at the Dom rebenka, who expresses sorrow, anger, and shame that so many mothers are "refusing to be mothers," and sending Russia's children abroad to be raised by foreigners.

Within this context, the viewers might expect the filmmaker to present Vera (Vanya's mother) equally negatively. After all, she abandoned her child at birth and has evidently made no attempt to contact him, whereas even the unstable, alcoholic Mukhina has done her best to reunite with her son. Kravchuk offers no explanation or justification for Vera's behavior. Perhaps aware that he cannot negotiate the gulf between outrage at mothers who abandon their children and Vanya's desperate need for his mother, he chooses to silence the character almost completely. She remains a shadowy figure who appears only in the background of one scene: she is evidently a nurse in the local hospital. When Vanya appears on her doorstep, her single line is “Ты меня ищешь, мальчик?” The viewer does not see her at that point; Kravchuk trains the camera on Vanya, whose remarkable expression of joy, tenderness, shyness, and relief is the film's final image. In a voiceover, Vanya reveals that he and his mother are living together happily now. However, the fact that we never see mother and son in the same frame, nor do we hear Vera's voice beyond that line, emphasizes Kravchuk's ambivalence toward this character. The happy ending does not erase the tension and anxiety surrounding the mother figure.

While the two films include features of various generic categories (straightforward drama, quest narrative, road movie, fairy tale), they share a number of elements from melodrama. As Peter Brooks writes, "Melodrama starts from and expresses the anxiety brought by a frightening new world in which the traditional patterns of moral order no longer provide the necessary social glue" (Brooks 1995: 20). It is unsurprising, then, that melodrama would be particularly suited to the post-Soviet era of change and instability. The lack of resolution in both films points to a significant uncertainty about precisely how to heal the traumatized nation, how to develop an authentic national identity and give voice to a silenced Russia. Perhaps, these filmmakers are suggesting, Russia must develop new paradigms and cultural narratives, but the complex process of development is incomplete and ongoing.

These two films belong to the first years of the new millennium, what would turn out to be the early Putin years. Nearly fifteen years later Zviagintsev returned to the subject of orphanhood in his 2017 film, Neliubov (translated as Loveless). In an early scene, a divorcing couple argues bitterly about who will take custody of their twelve-year-old son. This is no Kramer vs. Kramer or tug of love, though. Neither parent wants the child and they coldly discuss a plan to relinquish him to a children's home, effectively choosing to orphan him. It is not the agonizing decision of desperate parents unable to provide for their offspring; 
these are comfortably middle-class individuals who want to rid themselves of every trace of their acrimonious marriage, including the child they produced together, in order to pursue new relationships. In a devastating cinematic moment, the audience can see that the boy has overheard the discussion and fully understands its implications, though the parents remain unaware of his presence. In this world, children are disposable and orphans are not victims of circumstance; they can be intentionally, capriciously created. However, the boy becomes neither an actual nor a functional orphan. Instead, he goes missing not long after this scene, and his parents are transformed into a state for which there is no word: they become parents without a child. This stunning and bleak film turns orphanhood on its head. While the earlier films offer a sense of some continuity with the past and at least a chance to create new cultural paradigms, though unresolved and ambiguous, Loveless removes even that qualified hope. It belongs to a different era. The immediate post-Soviet phase is over, and with it both the uncertainty and the creative cultural potential typical of that time. New cultural mythologies have been developed (or manufactured) in the contemporary landscape, but they provide neither principles nor comfort for the fractured family at the heart of this film. New narratives and prescribed codes of behavior have been imposed from above, but the great family is a sham and the small family a failure. The characters seem as lost as orphans alone in the wilderness.

\section{BIBLIOGRAPHY}

BROOKS, P. (1995), The Melodramatic Imagination: Balzac, Henry James, and the Mode of Excess, New Haven, Yale University Press.

BRODSKI, M. (2018), "The Figure of the Child as a Contradictory Signifier in Contemporary Russian Cinema," in The Child in World Cinema, Olson, D. (ed.), Lanham, Lexington Books, 215-235.

CARDullo, R. (2012), "Suffer the Children," CineAction, 89, 52-59.

CLARK, K. (2000), The Soviet Novel: History as Ritual, Bloomington, Indiana University Press.

FEDOROV, A. V. (2016), "Zapadnyi mir na sovetskom i rossiskom ekhranakh," Mediaobrazovanie, 4, 149-275.

Goscilo, H. (2010), Cinepaternity: Fathers and Sons in Soviet and Post-Soviet Film, Bloomington, Indiana University Press.

KUZNETSOV, P. (2006), “Otsy i synovia. Istoriia voprosa”, Seans, 21-22, 11-31.

PROKHOROV, A. (2002), "Soviet Family Melodrama of the 1940s and 1950s: From Wait for Me to The Cranes Are Flying," in Imitations of Life: Two Centuries of Melodrama in Russia, McReynolds, L. and Neuberger, J. (eds.), Durham, Duke University Press, 208-231.

Prokhorov, A. (2007), "The Adolescent and the Child in the Cinema of the Thaw," Studies in Russian and Soviet Cinema, 1(2), 115-129.

Romney, J. (2018), “The Lost Boy," Sight and Sound, 28(3), 32-36. 
SARKISOVA, O. (2008), Past for the Eyes: East European Representations of Communism in Cinema and Museums after 1989, Budapest, Central European Press.

SEKATSKII, A. (2006), “Ottsepriimstvo,” Seans, 21-22, 34-47.

STRUKHOV, V. (2007), “The Return of Gods: Andrei Zviagintsev's Vozvrashchenie (The Return)," Slavic and East European Journal, 51(2), 331-356.

VICKS, M. (2011), “Andrei Zviagintsev's The Return (Vozvrashchenie 2003)," Kinokultura, 32. Available at: <http://www.kinokultura.com/2011/32rrreturn.shtml>.

Woll, J. (2000), Real Images: Soviet Cinema and the Thaw, London, I. B. Tauris. 